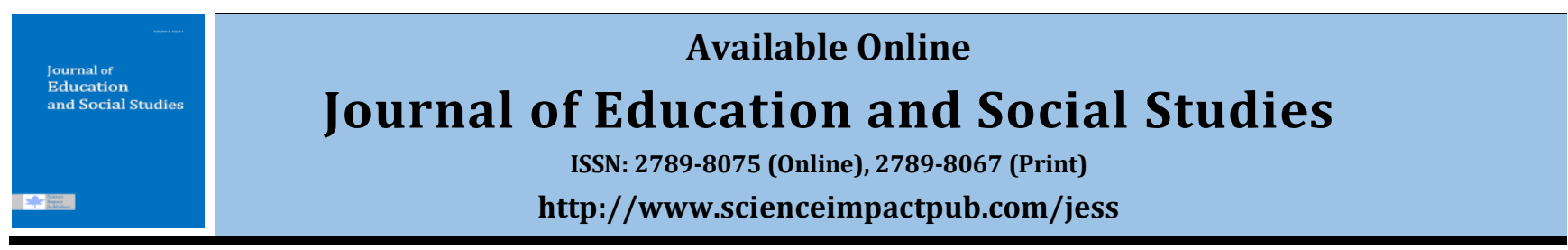

\title{
IMPACT OF PUBLIC DEBT ON HEALTH AND EDUCATION IN SAARC COUNTRIES
}

\author{
Hassan Tasleem \\ ${ }_{1}^{1}$ M.Phil. Scholar. Department of Economics, University of Lahore, Sargodha Campus, Sargodha, Pakistan
}

\begin{abstract}
The present study has done to investigate the impact of external debt servicing on health and education spending for the panel of selected SAARC countries (Bangladesh, India, Pakistan and Sri Lanka) are basically developing countries of Asia. This study uses two models of education spending and the other is for health spending by using the data set for 1990-2016 and estimations are carried out by using fixed effect model. Beside other explanatory variables debt servicing is the most important determinant of education spending and health spending and confirm the literature view that high external debt leads to increase in debt servicing liabilities and government do repayment of debt servicing by cutting its expenditure especially on health and education spending as it is easy for government to cut down the social sector spending rather than other sector spending. Other variable Tax revenue and Gross Capital Formation also effect the health and education spending but debt servicing liability effect more. It is best for SAARC countries to use and organize their own resources efficiently and less dependence on external debt and on foreign borrowing and give high attention to education and health spending.
\end{abstract}

Keywords: Public Debt; Health; Education; SAARC; GDP; ARDL.

Email: raohasan25@gmail.com

https://doi.org/10.52223/jess.20212203

(C) The Author(s) 2021.

This is an open access article under the CC BY license (http://creativecommons.org/licenses/by/4.0/).

\section{INTRODUCTION}

In the current testing day and age each economy wants to accomplish the monetary welfare and maintainable financial development. Each economy uses its own assets to accomplish the want level of welfare yet because of deficient assets and restricted spending plan there remain exist shortfall in their financial spending plan. To satisfy this hole countries interest for help and take overwhelming obligation from different countries and world establishments like International Fund (IMF) and World Bank are best of the rundown in this viewpoint. Outside obligation for creating nations is an essential stimulator of financial development for a nation and it's an approach to adjust the shortfall spending plan of a nation (Bank, 2014).

Outer obligation is viewed as fundamental for the creating nations since it's a route in towards remote assets to back imports that are required for improvement ventures. This outer obligation might be helpful in the short run yet it has outcomes over the long haul as nation needs to pay obligation overhauling risk on that outside obligation. Outer obligation is useful in short run just when if that obligation is used in well proficient and beneficial ventures than it will give return over the long haul for reimbursement of obligation liabilities. Albeit International Monetary Fund (IMF) has received numerous basic changes to diminish the volume of obligation load on creating nations yet these projects don't functioned admirably in creating Asian nations. Low pay nations dependably need to confront a hole in their spending shortage and to defeat this nation needs to hand-off on remote guide and outer borrowings. The private division of these creating nations don't make interest out in the open welfare extends so just government needs to made interest in social spending segment. Creating nations needs to do effective utilization of obtained 
subsidizes and make interest in beneficial activities and in social segment spending since it is difficult for state bank to print hard cash that is expected to reimburse the outside obligation (Rais \& Anwar 2012).

Created nations likewise take outside obligation and utilize that obligation in gainful and improvement projects to accomplish more welfare as these nations use their obligation being developed undertakings like infra-structure, development, vitality age and social spending ventures like wellbeing and training. Improvement of these segments is extremely basic to lift up the expectation for everyday comforts of people's. UN General Assembly allowed the task of Millennium Development Goal (MDGs) in 2003,which coordinated to destroy destitution and hunger and give better wellbeing and essential instruction offices however the vast majority of the creating nations stay in their horrendous obligation circle and primary spotlight on "welfare" ought to be occupied to" survival". Creating nations chop down their uses and pay obligation liabilities and it give ominous effect on welfare and bring joblessness up in the nation.

High obligation leads towards awesome adjusting liabilities and the vast majority of the creating nations increment their reliance on outside obligation and that obtaining is generally utilized marker of obligation to GDP proportion.Debt to GDP proportion tell about the development rate of obligation and development rate of genuine GDP. Expanding obligation to GDP proportion demonstrates that development rate of genuine GDP is not as much as development rate of obligation and it will end up being a significant circumstance when volume of outside acquiring end up noticeably unsustainable.

Social area spending assumes an imperative part in deciding the financial development of a nation. It incorporates spending on social helpful projects like wellbeing, instruction, security nets and sanitation consumptions. Government chop down consumption on wellbeing and instruction to meet its monetary hole. Obligation adjusting greatly affects these on goings ventures. However spending on wellbeing and instruction don't give return at the spot or in the short run it give brings about long run, in this way the vast majority of the nations avoid the assignment of assets in social spending and high obligation on obligation adjusting shift the assets from social sectors (Fosu, 2008).

In 1990, obligation emergency was in crest in the creating nations. Low salary nations dependably need to confront a monetary deficiency. To defeat this shortage these creating nations need to rely upon remote guide and outside obligation. In this condition they pay a noteworthy offer of their financial plan for obligation adjusting. Following outline demonstrates the outside obligation adjusting of chose SAARC nations.

On the off chance that this circumstance proceeds than quite possibly Sri-Lanka may fall in a genuine obligation trap. Obligation adjusting isn't an issue if obliged nation can produce enough incomes from its assets to administration of outside obligation without affecting financial development. The reliance on outside obligation fluctuates in various eras. Obligation adjusting of Pakistan and India begins to increment in 1990s. In spite of the fact that India influenced extraordinary approaches to diminish its obligation to trouble yet couldn't diminish its obligation weight to want level. Pakistan is another real economy of SAARC nations; the obligation load in Pakistan in 1990's additionally increments from 30 percent of its GDP to 59 percent of its GDP.

If there should be an occurrence of Bangladesh and Sri-Lanka same obligation issues are dung by them. Past examination on Bangladesh demonstrates that obligation load emphatically impacts the monetary development instead of the deficiency (Islam and Dawais, 2005). While in the event of Sri-Lanka past investigation initiated that Sri-Lanka not accomplish the alluring focuses for which obligation was collected

Outer obligation impact the social area spending both decidedly (upgrade these uses) and furthermore contrarily (obligation liabilities trim down these uses). In sub Saharan nations outer obligation demonstrates as limitation in method for social spending. In 2007 Shelton demonstrate negative connection between outside obligation and social segment spending for 100 nations that with high outer 
obligation social spending of wellbeing and instruction is diminished. While in Kenya there exists a positive connection between both. With the expansion in outer obligation the social use on wellbeing and training are helped up (Njeru, 2003). Economic hypothesis propose that when there come increment in social segment spending it will raise the social welfare of the nation and create work openings over the long haul by expanding family unit wage, access to sustenance, instruction and wellbeing as it diminishes the financial assorted variety

For monetary advancement economies make greater speculation on their foundation and on other formative ventures as opposed to doing uses in social segment. Since the profits on formative tasks are gotten before as contrast with the arrival on social part spending.

Numerous investigations assess the effect of outer obligation on social division spending in numerous nations yet it needs more investigation concerning instruction and wellbeing segment spending. Introduce think about is a push to check the effect of outer obligation overhauling on wellbeing and training parts independently. For this reason I have chosen a board of SAARC nations (Bangladesh, India, Pakistan and Sri Lanka). The focal point of this examination is to discover that to what expand instruction and wellbeing part spending is influenced by obligation overhauling liabilities in these chose SAARC nations. For monetary advancement economies make greater speculation on their foundation and on other formative ventures as opposed to doing uses in social segment. Since the profits on formative tasks are gotten before as contrast with the arrival on social part spending.

Shabbir and Yasin (2015) check the effect of open outside obligation on social spending on chose Asian creating nations by utilizing board informational collection for the day and age of 1980-2010. Their investigation depends on interrelated three distinct conditions of spending classifications by utilizing GMM strategy. The outcome expresses that outer obligation and obligation risk has offensive effect on open spending especially on social segment spending basically concentrating on wellbeing and training consumptions. Wu et al. (2010) endeavor to check the connection between general government use and improvement spending by taking the board information of 182 nations arranged by their pay level for the day and age of 1950-2004 by applying Granger Causality Test on it. The outcomes expresses that in high salary nations government spending builds people in general welfare and their monetary advancement however on account of low pay nations because of debasement and immature organizations government spending has little effect on their financial development.

Malik et al. (2010) measures the effect of outer obligation on the monetary execution of Pakistan for the day and age of 1972-2005 by utilizing time arrangement econometric methods and finds that outside obligation is contrarily identified with financial development. Increment in outside obligation prompts decrease in the monetary development. Obligation adjusting has likewise negative effect on GDP. Hassan and Butt (2008) check the connection between monetary development, exchange, outer obligation, work power and training in long run and short keep running in Pakistan for the era of 1975-2005 by utilizing ARDL to Co joining system and locate that aggregate obligation isn't a critical determinant of financial development either in long run or short run. Results clarify that obligation isn't use for beneficial reason in Pakistan and it's a noteworthy reason for moderate financial development of Pakistan.

Hyman (2007) check the effect of obligation on development and advancement of Caribbean states by taking information of obligation GDP proportion for 1997-2006 and infer that because of overwhelming obligation weight and obligation overhauling risk government will undoubtedly diminish its spending on their essential social administrations and infra structure improvement. Lora \& Olivera (2007)considered that whether increment out in the open obligation influences the social uses by utilizing test of 50 Latin American nations for the era of 1985-2003 and finds that high obligation decrease the social spending. Because of increment under water, social uses are severely influenced. Fosu (2007) examined on outer obligation - overhauling requirements and open use by utilizing board information of 35 African nations 
for the day and age of 1975-94 and infer that obligation imperative had negative effect on wellbeing and training uses. He likewise finds that obligation overhauling imperative is at risk to move open use far from the social segments (wellbeing and instruction).

Lora and Olivera (2007) examined that whether increment in broad daylight obligation influences the social consumptions by utilizing test of 50 Latin American nations for the day and age of 1985-2003 and finds that high obligation decrease the social spending. Because of increment paying off debtors, social consumptions are severely influenced.

Fosu (2007) contemplated on outside obligation - overhauling imperatives and open use by utilizing board information of 35 African nations for the day and age of 1975-94 and presume that obligation requirement had negative effect on wellbeing and training consumptions. He additionally finds that obligation adjusting imperative is at risk to move open use far from the social areas (wellbeing and instruction). Baqir (2002) check the effect of political and institutional factors on social segment spending in the creating nations by utilizing the "flexibility list" as an intermediary for the level of majority rules system and political structure which is the essential determinant of government spending by utilizing board informational index of more than 100 nations for the day and age of 1985-98 by applying OLS technique for estimation and reason that there is a solid connection amongst democratization and government spending particularly on social division spending, which demonstrates that social spending acquires consideration in vote based nations. Stephens (2001) contends that obligation adjusting swarms out open part "speculation spending" by utilizing board information for 24 African nations and result demonstrates that expansion under water overhauling has unfavorable effect on open spending, however with the bigger effect on later.

\section{METHODOLOGY}

Model and Methodology specification: To estimate the effect of external debt servicing for fiscal allocations on health and education the following two models are utilized.

$$
\begin{aligned}
& \text { Health }=\alpha_{0}+\alpha_{1} D E S R_{i t}+\alpha_{3} D E X P_{i t}+\alpha_{4} M L E_{i t}+\alpha_{5} C P I_{i t}+\alpha_{6} C T F_{i t} \\
& \text { Education }=\beta_{0}+\beta_{1} D E S R_{i t}+\beta_{3} D E X P_{i t}+\beta_{4} M L E_{i t}+\beta_{5} C P I_{i t}+\beta_{6} C T F_{i t}
\end{aligned}
$$

$D E S R_{i t}=$ Debt Servicing

$D E X P_{i t}=$ Development Expenditures

$M L E_{i t}=$ Military Expenditures

$C P I_{i t}=$ Corruption Perspective Index

$C T F_{i t}=$ Capital Farmation

Where $t$ and $i$ shows the time periods and countries respectively ( $\mathrm{i}=1,2 . .4 \& \mathrm{t}=199$ to 2016). Debt.ser ${ }_{i t}$ is the external debt servicing of these countries taken as external debt servicing as percentage of GDP. Previous literatures estimations explained that debt servicing always have adverse effect on social sector spending especially on health and education. Lora and Olivera (2007) examined that an increase in debt servicing results in decrees in social spending (health and education). While $\mathrm{TREV}_{\text {it }}$ is taken as control variable and it is the revenues collected by i countries for time periods $t$. Tax revenues always shows a significant and positive impact on social sector spending. Julie Lochard et al. (1998) found a significant and positive impact health and education spending. DEXP ${ }_{\text {it }}$ is another control variable. It is the developmental expenditures taken as percentage as GDP. These developmental expenditures include expenditure on infra-structure development, electricity production, purchase of equipment and other high return developmental projects. Every model technique has its own merits and demerits. To estimate this model the fixed effect model regression is estimated after estimating hauseman test by following Javed et al. (2016) and Fatima et al. (2019). As it controls many deficiencies which remain unobserved in data. Variables Data and Source: Data 
is for major SAARC countries (Bangladesh, India, Pakistan and Sri-lanka) for the time period 1990 to 2016 is taken from world development indicators. The data source and its definition are given in following Table1.

Table 1. Variables, Definitions and data source.

\begin{tabular}{|l|l|l|}
\hline Variables & Definition & Source \\
\hline DSER & External debt servicing as percentage of GDP & WDI \\
\hline DEXP & Development expenditures as percentage of GDP & WDI \\
\hline EDU & $\begin{array}{l}\text { Dependent variable taken government expenditures on education as } \\
\text { percentage of GDP }\end{array}$ & WDI \\
\hline HEA & $\begin{array}{l}\text { Dependent variable taken government expenditures on health as } \\
\text { percentage of GDP }\end{array}$ & WDI \\
\hline CPI & Corruption perspective index & PENN TABLE \\
\hline
\end{tabular}

\section{RESULTS AND DISCUSSION}

When health is dependent and CPI, DEBT. CAP and MIL is independent variable, results of ARDL model presented in Table 2 indicating that the error correction coefficient estimated at -0.764 is highly significant, has the correct negative sign, and imply low speed of adjustment to equilibrium. According to Banerjee et al. (2003) as cited in kidanemarim 2014, the highly significant error correction term further confirms the existence of a stable long run relationship. Moreover, the coefficient of the error term (ECM-1) implies that the deviation from long run equilibrium level of (dependent variable) of the current period is corrected by 76 percent in the next period to bring back equilibrium.

Table 2. ARDL analysis for health (Long run and short run).

\begin{tabular}{|c|c|c|c|c|}
\hline \multicolumn{5}{|c|}{ Dependent Variable: D(HEL) } \\
\hline \multicolumn{5}{|l|}{ Method: ARDL } \\
\hline \multicolumn{5}{|c|}{ Date: $02 / 22 / 18$ Time: $19: 20$} \\
\hline \multicolumn{5}{|l|}{ Sample: 20022016} \\
\hline \multicolumn{5}{|c|}{ Included observations: 70} \\
\hline \multicolumn{5}{|c|}{ Maximum dependent lags: 2 (Automatic selection) } \\
\hline \multicolumn{5}{|c|}{ Model selection method: Akaike info criterion (AIC) } \\
\hline \multicolumn{5}{|c|}{ Dynamic regressors (1 lag, automatic): CAP DEBT MIL CPI } \\
\hline \multicolumn{5}{|l|}{ Fixed regressors: $\mathrm{C}$} \\
\hline \multicolumn{5}{|c|}{ Number of models evalulated: 2} \\
\hline \multicolumn{5}{|c|}{ Selected Model: ARDL(2, 1, 1, 1, 1) } \\
\hline \multicolumn{5}{|c|}{ Note: final equation sample is larger than selection sample } \\
\hline \multicolumn{5}{|l|}{ Long Run Equation } \\
\hline Variables & Coefficient & Std. Error & t-Statistic & Prob.* \\
\hline CAP & -0.019905 & 0.007756 & -2.566304 & 0.0138 \\
\hline DEBT & 0.049923 & 0.026482 & 1.885143 & 0.0660 \\
\hline MIL & -0.244862 & 0.050789 & -4.821146 & 0.0000 \\
\hline CPI & 5.700982 & 2.656740 & 2.145856 & 0.0374 \\
\hline \multicolumn{5}{|l|}{ Short Run Equation } \\
\hline Variables & Coefficient & Std. Error & t-Statistic & Prob.* \\
\hline COINTEQ01 & -0.764459 & 0.364556 & -2.096958 & 0.0418 \\
\hline $\mathrm{D}(\operatorname{HEL}(-1))$ & 0.093463 & 0.271979 & 0.343641 & 0.7328 \\
\hline $\mathrm{D}(\mathrm{CAP})$ & 0.041263 & 0.032556 & 1.267461 & 0.2117 \\
\hline $\mathrm{D}(\mathrm{DEBT})$ & -0.061089 & 0.066086 & -0.924382 & 0.3603 \\
\hline $\mathrm{D}(\mathrm{MIL})$ & 0.265701 & 0.082898 & 3.205145 & 0.0025 \\
\hline $\mathrm{D}(\mathrm{CPI})$ & -10.26085 & 17.88676 & -0.573656 & 0.5691 \\
\hline $\mathrm{C}$ & 153.6738 & 72.86083 & 2.109142 & 0.0407 \\
\hline Mean dependent var & 1.106303 & S.D. depen & & 14.76475 \\
\hline
\end{tabular}




\begin{tabular}{|l|l|l|l|}
\hline S.E. of regression & 9.367569 & Akaike info criterion & 6.898491 \\
\hline Sum squared resid & 3861.059 & Schwarz criterion & 7.879852 \\
\hline Log likelihood & -230.1427 & Hannan-Quinn criter. & 7.290691 \\
\hline *Note: p-values and any subsequent tests do not account for model selection. \\
\hline
\end{tabular}

When education is dependent and CPI, DEBT, CAP, MIL are independent variables, the results of ARDL model presented in table 3 indicating the similar results, error correction coefficient estimated at -0.215 is highly significant, with correct negative sign, and imply again low speed of adjustment to equilibrium. The highly significant error correction term further confirms the existence of a stable long run relationship. Moreover, the coefficient of the error term (ECM-1) implies that the deviation from long run equilibrium level of (dependent variable) of the current period is corrected by 21 percent in the next period to bring back equilibrium.

Table 3. ARDL analysis for education (Long run and short run).

\begin{tabular}{|c|c|c|c|c|}
\hline \multicolumn{5}{|c|}{ Dependent Variable: D(EDU1) } \\
\hline \multicolumn{5}{|l|}{ Method: ARDL } \\
\hline \multicolumn{5}{|c|}{ Date: $02 / 22 / 18$ Time: $19: 23$} \\
\hline \multicolumn{5}{|c|}{ Sample: 20022016} \\
\hline \multicolumn{5}{|c|}{ Included observations: 72} \\
\hline \multicolumn{5}{|c|}{ Maximum dependent lags: 2 (Automatic selection) } \\
\hline \multicolumn{5}{|c|}{ Model selection method: Akaike info criterion (AIC) } \\
\hline \multicolumn{5}{|c|}{ Dynamic regressors (1 lag, automatic): CAP DEBT MIL CPI } \\
\hline \multicolumn{5}{|c|}{ Fixed regressors: $\mathrm{C}$} \\
\hline \multicolumn{5}{|c|}{ Number of models evalulated: 2} \\
\hline \multicolumn{5}{|c|}{ Selected Model: $\operatorname{ARDL}(1,1,1,1,1)$} \\
\hline \multicolumn{5}{|c|}{ Note: final equation sample is larger than selection sample } \\
\hline \multicolumn{5}{|l|}{ Long Run Equation } \\
\hline Variable & Coefficient & Std. Error & t-Statistic & Prob.* \\
\hline CAP & 0.066786 & 0.033751 & 1.978787 & 0.0536 \\
\hline DEBT & -0.096808 & 0.108197 & -0.894737 & 0.3754 \\
\hline MIL & 0.734254 & 0.178319 & 4.117633 & 0.0001 \\
\hline $\mathrm{CPI}$ & 70.79198 & 21.15715 & 3.346007 & 0.0016 \\
\hline \multicolumn{5}{|l|}{ Short Run Equation } \\
\hline Variable & Coefficient & Std. Error & t-Statistic & Prob.* \\
\hline COINTEQ01 & -0.215749 & 0.177670 & -1.214323 & 0.2306 \\
\hline $\mathrm{D}(\mathrm{CAP})$ & 0.026530 & 0.063244 & 0.419481 & 0.6767 \\
\hline D(DEBT) & 0.039799 & 0.016118 & 2.469199 & 0.0172 \\
\hline $\mathrm{D}(\mathrm{MIL})$ & 0.201206 & 0.242585 & 0.829427 & 0.4110 \\
\hline $\mathrm{D}(\mathrm{CPI})$ & -12.76338 & 4.677467 & -2.728696 & 0.0089 \\
\hline $\mathrm{C}$ & -76.38492 & 59.71503 & -1.279157 & 0.2070 \\
\hline Mean dependent var & -0.515868 & \multicolumn{2}{|c|}{ S.D. dependent var } & 23.86369 \\
\hline S.E. of regression & 20.53179 & \multicolumn{2}{|c|}{ Akaike info criterion } & 8.397038 \\
\hline Sum squared resid & 20234.61 & \multicolumn{2}{|c|}{ Schwarz criterion } & 9.255729 \\
\hline Log likelihood & -291.0874 & \multicolumn{2}{|c|}{ Hannan-Quinn criter. } & 8.740212 \\
\hline
\end{tabular}

\section{CONCLUIONS}

The present study has done to investigate the impact of external debt servicing on health and education spending for the panel of selected SAARC countries (Bangladesh, India, Pakistan and Sri Lanka) are basically developing countries of Asia. This study uses 2 models education spending and the other is for health spending by using the data set for 1990-2015 and estimations are carried out by using fixed effect 
model. Beside other explanatory variables debt servicing is the most important determinant of education spending and health spending and confirm the literature view that high external debt leads to increase in debt servicing liabilities and government do repayment of debt servicing by cutting its expenditure especially on health and education spending as it is easy for government to cut down the social sector spending rather than other sector spending. Other variable Tax revenue and Gross Capital Formation also effect the health and education spending but debt servicing liability effect more. It is best for SAARC countries to use and organize their own resources efficiently and less dependence on external debt and on foreign borrowing and give high attention to education and health spending.

\section{REFERENCES}

Bank, W. (2014). World development indicators 2014. The World Bank.

Banerjee, A., Dolado, J., \& Mestre, R. (1998). Error-correction mechanism tests for cointegration in a singleequation framework. Journal of time series analysis, 19(3), 267-283.

Baqir, R. (2002). Social Sector Spending in a Panel of Countries. International Monetary Fund.

Fatima, K., Nisar, U., \& Yasmin, H. (2019). Factors affecting the bilateral trade of Pakistan with major trading partners. Journal of Economic Impact, 1(1), 19-28.

Fosu, A. K. (2007). Fiscal allocation for education in sub-Saharan Africa: implications of the external debt service constraint. World Development, 35(4), 702-713.

Fosu, A. K. (2008). Implications of the external debt-servicing constraint for public health expenditure in sub-Saharan Africa. Oxford Development Studies, 36(4), 363-377.

Hasan, A., \& Butt, S. (2008). Role of Trade, External Debt, Labor Force and Education in Economic Growth Empirical Evidence from Pakistan by using ARDL Approach. European Journal of Scientific Research, 20(4), 852-862.

Hyman, R. (2007). The impact of high debt burdens on small Caribbean states. International Research Journal of Finance and Economics.

Javed, I., Ashfaq, M., Adil, S. A., \& Bakhsh, K. (2016). Analysis of agricultural trade between Pakistan and United Arab Emirates: an application of gravity model. Journal of Agricultural Research (03681157), 54(4).

Lora, E., \& Olivera, M. (2007). Public debt and social expenditure: Friends or foes? Emerging Markets Review, 8(4), 299-310.

Malik, S., Hayat, M. K., \& Hayat, M. U. (2010). External debt and economic growth: Empirical evidence from Pakistan. International Research Journal of Finance and Economics, 44(44), 1450-2887.

Njeru, J. (2003). The impact of foreign aid on public expenditure: The case of Kenya (AERC Research Paper 135). Nairobi, Kenya: African Economic Research Consortium.

Rais, S. I., \& Anwar, T. (2012). Public debt and economic growth in Pakistan: A time series analysis from 1972 to 2010. Academic research international, 2(1), 535.

Shabbir, S., \& Yasin, H. M. (2015). Implications of public external debt for social spending: a case study of selected asian developing countries. The Lahore Journal of Economics, 20(1), 71.

Stephens, M. (2001). External debt, government spending and growth in heavily indebted poor countries. Unpublished PhD thesis, New York University, NY.

Wu, S.-Y., Tang, J.-H., \& Lin, E. S. (2010). The impact of government expenditure on economic growth: How sensitive to the level of development? Journal of Policy Modeling, 32(6), 804-817. 